\title{
SUMARNI INVENTAR FONDA MJESNI NARODNI ODBOR VRH 1947. - 1952.
}

\author{
Jasna MRKONJIĆ \\ Državni arhiv u Pazinu \\ Pazin, Vladimira Nazora 3 \\ jasna.mrkonjic@dapa.hr
}

UDK 352.07(497.571)(083.22)“1947/1952”

\author{
Stručni rad
}

\begin{abstract}
Arhivskim gradivom fonda HR-DAPA-226 obuhvaćeno je gradivo nastalo djelovanjem stvaratelja Mjesnoga narodnog odbora Vrh u razdoblju 1947. - 1952. godine. Premda je sačuvano fragmentarno, gradivo svjedoči o radu upravnoga tijela na lokalnoj razini. Fond je sređen 2016. godine te je izrađen i sumarni inventar. Korišten je višerazinski sustav arhivističkoga opisivanja za pružanje informacija o stvaratelju gradiva te o samom gradivu. U inventaru je i osvrt na poslijeratne okolnosti uspostave državnih upravnih tijela na području Istre po svršetku rata.
\end{abstract}

Ključne riječi: Mjesni narodni odbor Vrh, Istra, sumarni inventar, upravno tijelo Keywords: Local People's Committee of Vrh, Istra, summary inventory, administrative authority

Parole chiave: Comitato popolare locale di Vetta, Istria, inventario sommario, organo amministrativo

\section{ARHIVISTIČKI OPIS FONDA}

\author{
HR-DAPA-226 MJESNI NARODNI ODBOR VRH
}

\section{IDENTIFIKACIJA}

\section{Identifikacijska oznaka / signatura}

HR-DAPA-226

\section{Naslov}

Mjesni narodni odbor Vrh

\section{Vrijeme nastanka gradiva}

1947-1952 


\section{Razina opisa}

Fond

\section{Količina i nosač jedinice opisa}

1 knjiga, 3 kutije, 0,31 d/m.

\section{KONTEKST}

\section{UPRAVNA POVIJEST STVARATELJA I POVIJEST FONDA}

\section{Stvaratelj}

Mjesni narodni odbor Vrh

\section{Normirani oblik naziva}

Mjesni narodni odbor Vrh

\section{Razdoblje djelovanja stvaratelja}

1945. - 1952.

\section{Sjedište}

Vrh

\section{Pravni položaj}

Tijelo državne uprave - jedinica lokalne razine

\section{Funkcije i djelatnost}

Općim zakonom o narodnim odborima ${ }^{1}$ određeni su njihovi zadatci i nadležnosti. Narodni su odbori bili najviši organ državne vlasti na teritoriju koji su pokrivali te su birani kao predstavnički organi tajnim glasovanjem na temelju općega, jednakog i neposrednog izbornog prava. U okviru su svoje nadležnosti obnašali vlast i donosili opće propise sukladno odredbama saveznoga i republičkog ustava, saveznih i republičkih zakona te općih propisa državnih tijela i organa. Ovisno o veličini teritorija, osnivani su od najmanjih teritorijalno-administrativnih jedinica (sela i manjih gradova) do okruga/oblasti, uključujući u njima mjesta, gradove i kotare. Za najmanja su administrativno-teritorijalna područja, sela i manje gradove, osnivani mjesni narodni odbori. Zadatci su mjesnih narodnih odbora opisani čl. 26 Općega zakona o narodnim odborima gdje se pored obavljanja temeljnih poslova predviđaju i zadatci na »ostvarenju poljoprivrednog plana, materijalno kulturnom

1 Službeni list FNRJ, br. 43/1946. 
podizanju mjesta, rukovođenju komunalnim zadacima, rad na unaprjeđenju obrta i mjesne industrije, te posredovanje u razmjeni dobara između grada i sela ${ }^{2}{ }^{2}$

Zadatci su se mjesnih narodnih odbora konkretno realizirali u sljedećim aktivnostima u tim područjima:

- gospodarstvo i poljoprivreda (donošenje i ostvarivanje mjesnoga gospodarskog i poljoprivrednog plana, nadzor nad zadrugama i ostalim privrednim subjektima, upravljanje prirodnim resursima na području nadležnosti, praćenje poljoprivredne proizvodnje u području stočarstva, voćarstva, vinogradarstva, briga o šumama te sudjelovanje u agrarnoj reformi i kolonizaciji)

- komunalna djelatnost (briga i nadzor nad mjesnim infrastrukturnim objektima, vodoopskrbom, kanalizacijom, električnom energijom, prometom, javnom rasvjetom, potom upravljanje i nadzor nad javnim površinama te osnivanje mjesnih ustanova za potrebe lokalne zajednice, nadzor nad stambenim fondom, građevinskim radovima, mjesnim službama)

- trgovina i obrt (upravljanje i nadzor nad državnim mlinovima, nadzor nad lokalnim gospodarskim subjektima, odnosno obrtima, trgovačkim poduzećima, skrb o racionalnom raspolaganju i raspodjeli namirnica, praćenje cijena, zaliha trgovaca, mjesnih sajmišta)

- financije (donošenje mjesnoga proračuna, ubiranje mjesnih poreza te kontrola izvršenih obveza uplata i davanja poreznih obveznika i privrednih subjekata prema državi)

- prosvjeta i kultura (rad na kulturnom napretku mjesta putem organiziranih tečajeva opismenjavanja, potom osnivanjem i pomaganjem kulturnih društava i ustanova, kao što su čitaonice, domovi, kinematografi i sl., financiranje i praćenje rada osnovnih i srednjih škola te praćenje pohađanja nastave)

- javno zdravstvo i socijalna skrb (briga za potrebite, odnosno djecu bez odgovarajuće roditeljske skrbi, obitelji poginulih, žrtve fašističkog terora, osnivanje i upravljanje pučkim kuhinjama, skloništima, mjesnim ambulantama i zdravstvenim ustanovama, briga o poštivanju higijenskih propisa i briga o grobljima)

- ostala područja koja nisu uključena u jedno od prethodno navedenih (matičarstvo, vođenje administrativnoga i administrativno-kaznenoga postupka, evidencije stanovništva, distribucija pošte u mjestima bez poštanskih ureda, pomaganje pri regrutaciji, nadzor nad društvenim organizacijama mjesnoga značaja). ${ }^{3}$

\section{Izvori ovlasti}

Rad, ustroj i nadležnost mjesnih narodnih odbora određeni su zakonima, propisima i ukazima od 1945. do 1952. godine.

Na ist. $m j$.

3 U čl. 26 Općega zakona o narodnim odborima navedeni su detaljno razrađeni zadatci mjesnih narodnih odbora za svako područje rada. 
- Ukaz o proširenju važnosti Ustava, zakona i drugih propisa NRH na područje Istre, grada Rijeke i Zadra te otoka Lastova (NN NRH 87/47)

- Ukaz o priznavanju narodnih odbora na području Istre, gradova Rijeke i Zadra te otoka Lastova zakonitim organima vlasti (NN NRH 87/47)

- Opći zakon o narodnim odborima (NN 43/46)

- Odluka Oblasnog NO-a za Istru br. 6385-I-47 (Sl. list ONO za Istru i GNO Rijeka br. 14/47)

- Zakon o administrativno-teritorijalnoj podjeli Narodne Republike Hrvatske (NN 60/47)

- Zakon o izmjenama i dopunama Zakona o administrativnoj i teritorijalnoj podjeli Narodne Republike Hrvatske (NN 42/48)

- Zakon o administrativno-teritorijalnoj podjeli Narodne Republike Hrvatske (NN 29/49)

- Zakon o administrativno-teritorijalnoj podjeli Narodne Republike Hrvatske (NN 27/50)

- Uputstvo o pripajanju područja ukinutih mjesnih narodnih odbora drugim administrativno-teritorijalnim jedinicama (NN 27/50)

- Zakon o podjeli Narodne Republike Hrvatske na kotare, gradove i općine (NN 16/52).

\section{Unutarnji ustroj}

Ovisno o veličini područja za koje su bili osnovani te broju stanovnika, a u skladu s normom propisanom republičkim zakonom te specifičnostima opsega i složenosti društvenih, socijalnih i ostalih čimbenika (»privrednih, kulturnih i drugih lokalnih odnosa«), određivan je brojni sastav narodnih odbora. Mjesni su narodni odbori u svom sastavu imali od 7 do 35 odbornika, uz predsjednika i tajnika koji su ujedno imali funkciju njihovih izvršnih organa. Kao najviši organi vlasti za područje koje su pokrivali, izvršavali su svoje dužnosti bilo neposredno na skupštini odbornika, bilo putem svojih izvršnih i upravnih organa. Njihov se rad temeljio na zakonima i drugim propisima, odlukama, naredbama, uputama i rješenjima. U okviru svoga djelovanja imali su pravo propisivati i kazne za povredu svojih propisa, u vidu lišenja slobode, prinudnoga rada bez lišenja slobode ili novčane kazne do određenoga iznosa.

\section{Sjednice MNO-a}

Zasjedanja su narodnih odbora bila redovna ili izvanredna. Redovna su sazivana sukladno Ustavom određenim rokovima, a izvanredna su sazivana bilo na inicijativu samoga narodnog odbora, bilo na traženje većine odbornika ili na zahtjev viših narodnih odbora, odnosno njihovih izvršnih odbora. Na prvoj je sjednici narodnoga odbora verifikacijska komisija potvrđivala punomoći izabranih odbornika, koji su potom prisezali. Predsjednik je mjesnoga narodnog odbora vodio sjednice te je ujedno bio i predsjednik izvršnoga odbo- 
ra. Sjednice su u pravilu bile javne ako nije iz opravdanih razloga bilo drugačije odlučeno. Za donošenje je pravovaljanih zaključaka i odluka bila potrebna većina glasova prisutnih odbornika. Prema ukazanoj potrebi za obavljanje važnijih poslova, poput pripremanja odluka, provođenja anketa i sl., narodni su odbori mogli osnivati i posebne odbore. Osim sudjelovanja na sjednicama narodnoga odbora, izabrani su odbornici mogli prisustvovati sjednicama upravnih organa ustanova i poduzeća na području svoga narodnog odbora ili nižih narodnih odbora na svom području. Ovo su pravo imali izričito odbornici koje je ovlastio njihov narodni odbor. Na području svoga narodnog odbora odbornici su imali imunitet te bez prethodnoga odobrenja izvršnoga odbora narodnog odbora kojem pripadaju, imunitet im nije mogao biti skinut niti su mogli biti lišeni slobode i odvedeni pred sud, osim u slučajevima počinjena zločina ili opasnosti od bijega. U slučaju počinjene štete proizašle iz nezakonita ili nepravilna rada, odbornici su materijalno odgovarali. Za svoj rad su odgovarali narodnom odboru, sukladno važećem poslovniku, a za počinjenje krivičnih djela u tijeku obavljanja službene dužnosti primjenjivani su propisi krivičnoga zakona. Za svoju dužnost odbornici u pravilu nisu primali naknadu, iako je narodni odbor mogao odobriti isplatu naknade onim odbornicima koji su bili zauzeti obavljanjem svojih dužnosti kao rukovodioci u odjelu ili odsjeku u tolikoj mjeri da se nisu bavili svojim redovnim poslovima. Odbornički je mandat prestajao u slučaju gubitka biračkoga prava, opozivom na temelju odluke birača, zbog trajnoga odlaska s teritorija narodnoga odbora te osudom za nečasno djelo.

\section{Zborovi birača}

Mjesni narodni odbori sazivali su zborove birača najmanje jednom u dva mjeseca, a ovisno o ukazanoj potrebi i češće te s obzirom na potrebu rješavanja aktualnih pitanja mjesta (sela). Iako su se sazivali prvenstveno radi sređivanja lokalnih problema, mogli su također raspravljati i o drugim pitanjima od interesa za širu društvenu zajednicu (kotar, oblast, republiku). Neovisno o ovome, zborovi birača mogli su se sazvati i na traženje najmanje jedne petine birača u mjestu, koji su onda mjesnom narodnom odboru predlagali i dnevni red, a samim je zborom rukovodilo izabrano predsjedništvo. Na sastancima se zborova birača vodio zapisnik sastanka, a o zaključcima je zbora birača raspravljao mjesni narodni odbor. Ovisno o situaciji, odnosno o samim zaključcima, izvršni je odbor, odnosno sam predsjednik, mogao odgovoriti pozitivno ili negativno na dostavljene prijedloge/ zaključke. U slučaju nepravilnosti ili nezakonitosti samih donesenih zaključaka ili ako su se oni odnosili na više organe, mjesni su ih narodni odbori prosljeđivali višim narodnim odborima, o čemu su izvještavali na idućem zboru birača.

\section{Izvršni odbor}

Pri narodnim odborima koji su pokrivali veće područje, formirani su izvršni odbori, koji su kao izvršni i upravni organi narodnih odbora ostvarivali zaduženja i poslove iz nadležnosti narodnih odbora, ako zakonom i pratećim propisima nisu stavljeni izravno u nadležnost narodnih odbora. Za svoj su rad izvršni odbori odgovarali nadležnom narod- 
nom odboru, a sačinjavali su ga predsjednik, podpredsjednik, tajnik i ostali članovi, osim u slučaju mjesnih narodnih odbora, koji su u početku imali samo predsjednika i tajnika, a kasnije uz njih najmanje još tri člana. Broj je članova izvršnoga odbora određivan sukladno republičkom zakonu te prema brojnom sastavu narodnoga odbora, kao i opsegu i složenosti poslova u njegovoj nadležnosti. Svoje je odluke izvršni odbor donosio na sjednicama većinom glasova članova. Izvršni je odbor radio sukladno odlukama, naredbama, uputama i rješenjima svoga narodnog odbora te uredbama, pravilnicima, uputama, naredbama i rješenjima viših upravnih tijela. Izvršni su odbori donosili općenite naredbe, upute i rješenja, koje su potpisivali predsjednik i tajnik. Za mjesne je narodne odbore bez izvršnoga odbora o poslovima iz svoje nadležnosti narodni odbor kao cjelina donosio odluke. U takvim su mjesnim narodnim odborima svim administrativnim poslovima rukovodili predsjednik i tajnik, izvršavajući njegove odluke te rješenja viših izvršnih odbora. U mjesnim izvršnim odborima nisu postojali odsjeci, već su u njima predsjednik i tajnik neposredno rukovodili pojedinim granama uprave. Ostali su članovi izvršnoga odbora pratili izvršenje zadataka te rukovodili poduzetim radovima i kampanjama u pojedinim granama državne uprave te nadzirali rad ustanova, poduzeća službenika odbora i obavljali ostale poslove iz nadležnosti odbora.

\section{Komisije}

Radi potrebe kvalitetnijega obavljanja posla te u slučajevima opsežnije i ambicioznije planiranih radnih zadataka, pri mjesnim su se narodnim odborima mogla formirati pomoćna tijela, kao npr. stalne ili povremene komisije, savjeti, aktivi, koji su se posebno i dodatno angažirali u izvršenju određenih zadataka. Stalne su komisije bile komisija za odluke, komisija za privredni plan i financije, mandatno-imunitetna komisija te komisija za molbe i žalbe, odnosno kod nižih odbora referent za molbe i žalbe.

\section{Administrativni rad}

Za obavljanje administrativnih i stručnih poslova narodni odbori imali su službenike rukovođene od strane izvršnoga odbora. Općim administrativnim poslovima rukovodio je tajnik, a vođenje je administrativno-tehničkih poslova bilo jedinstveno. Rad su mjesnih narodnih odbora nadzirali kotarski narodni odbori, čiji je zadatak bio pružanje pomoći, praćenje rada, davanje uputa i sl. podređenim mjesnim narodnim odborima. Izjave i zahtjevi saslušanih stranaka u administrativnom postupku unosili su u zapisnik, a o svakom se zahtjevu stranke moralo donijeti odgovarajuće rješenje s uputom na pravo žalbe odnosno prigovora. Žalbe su se u pravilu ulagale u roku od osam dana od primitka rješenja, a rješenje po žalbi donosilo se najkasnije u roku od trideset dana ako nije drugačije određeno. Svi su narodni odbori imali svoje službene nazive na jezicima narodnih republika, a one administrativno-teritorijalne jedinice u kojima žive nacionalne manjine i na jezicima tih manjina. 


\section{Opći kontekst}

Donošenjem Zakona o promjeni naziva narodnooslobodilačkih odbora od 25. 7. 1945., mijenja se njihov naziv i oni postaju narodni odbori, ustrojeni hijerarhijski te kao takvi raspoređeni na čitavom području Narodne Republike Hrvatske. Navedenim Zakonom od 25. 7. 1945. i narodnooslobodilački odbori s područja Istre, sukladno novonastalim okolnostima, odnosno okončanjem ratnih aktivnosti, mijenjaju svoje nazive i postaju narodni odbori. Prestankom rata narodni odbori postaju organi civilne vlasti te se njihovi zadatci i obveze usmjeravaju na organiziranje života u novim, poratnim, civilnim uvjetima. Ovisno o veličini područja za koje su bili osnovani, narodni su odbori pokrivali veća ili manja područja, u rasponu od oblasti i kotara, kao najvećih, do manjih mjesta i sela, kao najmanjih. Djelovali su kao narodni odbori mjesta, kotareva, gradskih rajona, gradova, okruga i oblasti. Mjesni su narodni odbori djelovali u sastavu kotarskih narodnih odbora, koji su im bili izravno nadređena tijela. Zakonom o administrativno teritorijalnoj podjeli $N R H^{5}$ iz 1947. godine područje se NRH administrativno dijelilo na oblasti koje su kao najveće teritorijalne jedinice unutar sebe imale kotareve, a koji su se dalje dijelili na još manje teritorijalne jedinice: gradove, gradske rajone, gradska naselja te područja mjesnih narodnih odbora, kao najnižih organa administrativnoga ustroja i civilne vlasti.

\section{Istra}

Kraj je rata Istra dočekala s teritorijalnom podjelom na sljedeće kotareve: Buje, Buzet, Čepić, Kras, Labin, Lošinj, Motovun, Pazin, Poreč, Rovinj, Tinjan, Umag, Vodnjan i Žminj, ukupno 14. U razdoblju do listopada 1947., do konačnoga integriranja u područje $\mathrm{NRH}$, došlo je do smanjenja broja kotareva na području Istre te se tako 1945. godine ukidaju kotarevi: Čepić, Rovinj, Tinjan i Umag, dok je kotar Žminj - Kanfanar ukinut 1946., a kotar Motovun 1947. godine. Sve su navedene teritorijalne izmjene izvršene prije listopada 1947., što je značilo da je područje Istre prije povezivanja s ostatkom zemlje bilo u jednom razdoblju administrativno organizirano u preko 7 kotarskih narodnih odbora te 3 gradska narodna odbora, unutar kojih je djelovalo 575 mjesnih narodnih odbora.

Na sjednici od 1. 9. 1947. ONO za Istru odlučio je da se i na području Istre počinju primjenjivati svi važeći pravni propisi koji su vrijedili u FNRJ i NRH. Istoga je dana također na izvanrednom zasjedanju ONO-a za Istru u Pazinu odlučeno, poštujući iskazanu težnju naroda Istre, a izrečenu na slobodnim izborima za Oblasnu narodnu skupštinu, koji su održani 25. 11. 1945., da se teritorij Istre priključi matičnom području, odnosno području NRH, unutar zajedničke državne tvorevine FNRJ. Ukazom o proširenju važnosti Ustava zakona i drugih propisa NRH na području Istre, gradova Rijeke i Zadra, te otoka Lastova, ${ }^{6}$ tek su od 1. 10. 1947. ova područja navedena u sastavu NRH. Nadalje, tim su Ukazom konačno i istarski narodni odbori, naslijedivši one nastale u ratu, dobili svoj zakonski le-

\footnotetext{
Narodne novine NRH, br. 3/1945.

Isto, br. 60/1947.

Isto, br. 87/1947.
} 
gitimitet. ${ }^{7}$ ONO za Istru prestao je djelovati 30. 11. 1947. jer više nisu postojali opravdani razlozi za njegovo produženo djelovanje kad je Istra integrirana u područje NRH. Odlukom Oblasnoga narodnog odbora za Istru br. 5858-47, od 21. 7. 1947. ${ }^{8}$, određuje se brojni sastav Kotarskoga narodnog odbora Kotara Buzet na način da se određuje 55 odbornika iz 15 mjesnih narodnih odbora te između njih i za MNO Vrh. Broj je mjesnih narodnih odbora u sastavu Kotara Buzet varirao u razdoblju od 1947. do 1949. godine te je 1947. bilo 17 mjesnih narodnih odbora, 1948. njihov je broj smanjen na 13, da bi ih 1949. godine bilo 15 u sastavu Kotarskoga narodnog odbora Buzet. ${ }^{9}$

Zakonom o administrativno-teritorijalnoj podjeli $N R H^{10}$ i Uputstva o pripajanju područja ukinutih mjesnih narodnih odbora drugim administrativno-teritorijalnim jedinica$m a^{11}$ Kotar Buzet postaje dijelom Oblasti Rijeka. Mjesni su narodni odbori, kao najniže jedinice lokalne uprave, postojali do 1952. godine kad se novim Zakonom o podjeli NRH na kotareve, gradove i općine $e^{12}$ mijenja upravni poredak te posljedično i teritorijalni ustroj, pa se ukidaju mjesni narodni odbori, a njihova se područja nadležnosti i funkcije prebacuju pod nadležnost gradskih i općinskih narodnih odbora. Prema je navedenom Zakonu područje Kotarskoga narodnog odbora Buzet obuhvaćalo šest narodnih odbora općina: Narodni odbor Općine Buzet, Narodni odbor Općine Dane, Narodni odbor Općine Gradin, Narodni odbor Općine Lanišće, Narodni odbor Općine Oprtalj, Narodni odbor Općine Roč. Mjesni narodni odbor Vrh ušao je u sastav Narodnoga odbora Općine Buzet. Postojeće je stanje zadržano do 1955. kada dolazi do nove teritorijalne podjele temeljem Zakona o osnivanju narodnih odbora novih općina $i$ kotareva. ${ }^{13}$

\section{VEZE}

Prva veza

Naziv/oznaka povezanoga Normirani oblik naziva entiteta

Vrsta veze

Opis veze

Nadnevci veze
Kotarski narodni odbor Buzet

KNO Buzet

Hijerarhijska

Nadređeno tijelo

1947-1952

\footnotetext{
$7 \quad$ Na ist. mj.

$8 \quad$ Službeni list ONO za Istru i GNO Rijeka, br. 13/1947.

9 Patricija ŽUŽIĆ, »Teritorijalno-administrativni ustroj na području današnje Istarske županije za razdoblje od 1945. do 1990. godine: prilog za izradu shematizma uprave«, Vjesnik istarskog arhiva, sv. 14 - 16 (2007. - 2009.), str. 213-215.

10 Narodne novine NRH, br. 27/1950.

$11 \quad$ Na ist. mj.

12 Isto, br. 16/1952.

13 Isto, br. 33/1955.
} 
J. MRKONJIĆ, Sumarni inventar fonda Mjesni narodni odbor Vrh 1947. - 1952. / VIA svezak 24

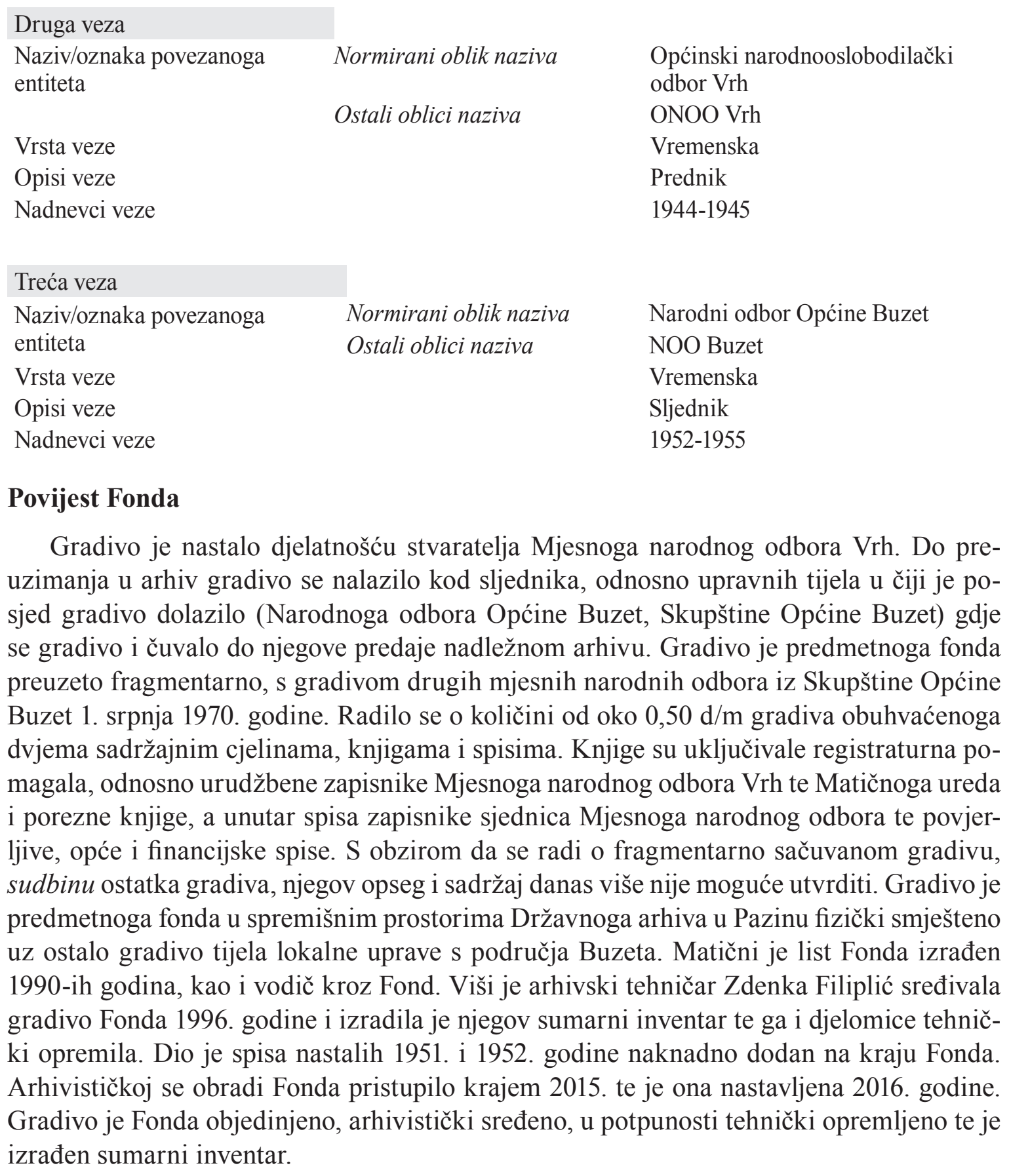

\section{Način preuzimanja ili predaje}

Gradivo fonda HR-DAPA-226, Mjesni narodni odbor Vrh, preuzeto je po službenoj dužnosti 1. 7. 1970. od Skupštine Općine Buzet, zajedno s gradivom drugih ukinutih bivših upravnih tijela s područja Buzeštine (narodnih odbora općina i mjesnih narodnih odbora), temeljem Zapisnika HAP br. 01-273/2-1970, od 28. 9. 1970. i br. 01-S 1311, od 28. 9. 1970. i temeljem još jednoga Zapisnika HAP br. 01-353/01-1971 od 14. 12. 1971. 


\section{SADRŽAJ I USTROJ FONDA}

\section{Sadržaj}

Gradivo je Fonda sačuvano fragmentarno. Budući da se radi o gradivu nastalom djelovanjem tijela lokalne uprave, sačuvani spisi svjedoče o zaduženjima i aktivnostima, u svezi s potrebama uže, lokalne zajednice. Mjesni narodni odbor Vrh bio je podređen Kotarskom narodnom odboru Buzet te gradivo većinom sadrži dopise, upute, preporuke, rješenja i sl. materijale, zaprimljene od nadređenoga tijela, prema kojima se poslovanje stvaratelja rukovodilo. Uz navedeno, Fond sadrži i gradivo u svezi s različitim društvenim, gospodarskim i drugim subjektima na koje je MNO Vrh u svom poslovanju bio upućen, odnosno s kojima je po prirodi posla surađivao. Gradivo sadrži i zapisnike sjednica MNO-a Vrh i njegovih upravnih organa te spise koji prikazuju općenito poslovanje stvaratelja, što se odnosi na planove i programe rada, izvješća, upute i sl. te registraturna pomagala (urudžbene zapisnike) MNO-a Vrh za poslovanje $u$ cijelosti, kao i urudžbene zapisnike Matičnoga ureda (dalje MU) i vojnoga odsjeka. Ostalo gradivo obuhvaća spise s područja djelatnosti stvaratelja $u$ užem smislu, uvjetno rečeno. Riječ je o gradivu u svezi s komunalnom djelatnošću, poslovima narodne obrane, odnosno vojnoga odsjeka, potom poljoprivredom i prosvjetom. Sadrži i spise u svezi s radnim odnosima, socijalnim i zdravstvenim pitanjima, trgovinom i opskrbom te unutarnjim poslovima i MU. Sadržaj navedenoga gradiva oslikava djelatnost mjesnih narodnih odbora te njihovo poslovanje kao lokalnoga tijela uprave pa ni gradivo predmetnoga fonda nije izuzetak u tom pogledu.

\section{Odabiranje i izlučivanje}

Gradivo je Fonda sačuvano fragmentarno. Evidentirani podatci o eventualnim izlučivanjima kod stvaratelja nisu zabilježeni, a također nema podataka o eventualnim izlučivanjima u fazi pohrane gradiva kod sljednika, što također ne znači da ih nije bilo. S obzirom na ukupnu količinu sačuvanoga gradiva, prilikom posljednje arhivističke obrade gradiva postupak odabiranja i izlučivanja nije proveden.

\section{Dopune}

S obzirom da je gradivo u DAPA-i preuzeto po službenoj dužnosti te da ne postoje saznanja o možebitnom postojanju dijela gradiva Fonda na terenu, u tom se smislu ne očekuju dopune Fonda. Dopune su moguće, pak, sređivanjem gradiva iste i slične provenijencije u DAPA-i gdje bi se eventualno unutar gradiva drugih fondova mogli nalaziti i fragmenti gradiva ovoga fonda, pri čemu se prvenstveno misli na druge MNO-e s područja Buzeta.

\section{Plan sređivanja}

\section{Zatečeno stanje}

Gradivo je Fonda zatečeno osnovno sređeno, kartonirano i popisano, što je urađeno nakon njegova preuzimanja u Arhiv, prilikom izdvajanja iz cjeline tada preuzetoga gradiva. Na navedenim su poslovima radile djelatnice Ljiljana Radaljac, viši arhivski tehničar, 
i Zdenka Filiplić, viši arhivski tehničar. Ljiljana Radaljac izradila je 1990-ih godina ML fonda, a Zdenka Filiplić izradila je 1996. godine sumarni inventar Mjesnoga narodnog odbora Vrh. Gradivo je Fonda prije sređivanja u spremišnim prostorima bio pohranjeno uz druge upravne fondove s područja Buzeta uz koje je bilo preuzeto. Tada je bilo i osnovno sređeno i popisano, da bi se njegovu sređivanju pristupilo kasnije, 1996. godine. Tom su prilikom formirane dvije funkcionalne cjeline gradiva, odnosno serije, knjige i spisi, prema uvriježenoj praksi sređivanja i popisivanja gradiva. Serijom knjige bila su obuhvaćena registraturna pomagala, kako ona koja su se odnosila na cjelokupno poslovanje stvaratelja, tako i ona koja su se odnosila na poslovanje određenih službi, referada, poput MU ili Vojne referade. Knjige su bile složene kronološki. Što se spisa tiče, oni su također bili razvrstani kronološki i popisani unutar svake godine, pri čemu je kronologija nastanka spisa bila osnovni kriterij njihova grupiranja. Ovisno o sadržaju sačuvanih spisa za pojedinu godinu, prvo su izdvajani zapisnici sjednica MNO-a, odnosno njegovih upravnih organa, a potom ostali spisi: birački popisi, spisi vojnoga odsjeka/referade, financijski itd. Unutar spisa, kao zasebna cjelina, bili su izdvojeni tzv. povjerljivi spisi, također kronološki, ovisno o godini nastanka. Unutar godine spisi su slagani po rednom broju. Spisi koji nisu bili navedeni kao povjerljivi, a ni sadržajno naznačeni kao spisi MU-a ili vojnoga odsjeka ili financijski spisi, odnosno svi oni preostali spisi, raznovrsna sadržaja, bez obzira na njega, bili su obuhvaćeni nazivom opći spisi te su razvrstani kronološki i složeni po rednom broju. Gradivo je Fonda nakon sređivanja bilo i djelomice tehnički opremljeno.

\section{Obrada 2016. godine}

Prije posljednje je obrade gradiva obavljen uvid u već spomenuto ranije sređeno gradivo Fonda te je uspoređen s postojećim obavijesnim pomagalom. Kako je evidentiranjem gradiva u spremišnim prostorima DAPA-e te sređivanjem gradiva drugih tijela lokalne uprave s područja Buzeta, dio gradiva predmetnoga fonda uočen izvan cjeline već sređenoga fonda, on je tijekom zadnje obrade priključen Fondu, a ranije sređeno gradivo preoblikovano je i razvrstano na serije s pripadajućim podserijama. Unutar nižih razina, podserija i još nižih pod-podserija gradivo je složeno kronološki, i po rednom broju gdje je to bio slučaj. U konačnici je uspostavljen sljedeći plan sređivanja:

\section{ORGANIZACIJA I UPRAVLJANJE}

2. EVIDENCIJE DOKUMENTACIJE

\section{DJELATNOST NARODNOGA ODBORA}




\section{DOSTUPNOST I KORIŠTENJE}

\section{Uvjeti dostupnosti i korištenja}

Fond ima status javnoga arhivskog gradiva, koje je dostupno sukladno Zakonu o arhivskom gradivu i arhivima ${ }^{14}$, Zakonu o zaštiti osobnih podataka ${ }^{15}$, Zakonu o pravu na pristup informacijama ${ }^{16}$ te Pravilniku o korištenju arhivskoga gradiva ${ }^{17}$.

\section{Uvjeti objavljivanja ili umnožavanja}

Objavljivanje i umnožavanje dostupnoga gradiva moguće je sukladno navedenim Zakonima i Pravilniku te Pravilniku o radu Čitaonice DAPA-e. Uvjeti se umnožavanja arhivskoga gradiva u svrhu njegova objavljivanja utvrđuju ugovorom između DAPA-e i korisnika gradiva.

\section{Jezik i pismo u gradivu}

Gradivo je Fonda pisano latiničnim pismom na hrvatskom jeziku, strojopisom i rukopisom, dok su manji dijelovi pisani na talijanskom jeziku.

\section{Tvarne značajke i tehnički uvjeti}

Većina je gradiva nastala na uredskom papiru. Dio je gradiva nastao na papiru iz blokova, bilježnica i sl. te na omotima, omotnicama, uložnicama za spise koji su korišteni u nedostatku pravoga uredskog papira. S obzirom na uvjete ranije pohrane, gradivo u manjoj mjeri ima mehanička oštećenja zbog načina pohrane i uporabe i kod stvaratelja i u kasnijim razdobljima skrbi, a dio gradiva također sadrži manja oštećenja nastala kao posljedica izlaganja utjecaju sunca i vlage, kao i manja oštećenja nastala uporabom metalnih spojnica koje su s vremenom korodirale.

\section{Obavijesna pomagala}

Registraturna pomagala

1. Urudžbeni zapisnik 1947., knj. 1

2. Urudžbeni zapisnik 1947.1951., knj. 2

3. Urudžbeni zapisnik 1948-1950., knj. 3

4. Urudžbeni zapisnik 1951-1952., knj. 4

5. Urudžbeni zapisnik Vojnoga odsjeka 1950., knj. 5

6. Urudžbeni zapisnik Matičnoga ureda 1950-1952., knj. 6

7. Registar izdavanja dokumenata 1947-1952., knj. 7.

\footnotetext{
NN 46/17.

NN 106/12.

$16 \mathrm{NN} 85 / 15$.

$17 \quad$ NN 67/99.
} 


\section{Arhivistička obavijesna pomagala} DAPA

1. HR-DAPA-226 Mjesni narodni odbor Vrh, sumarni inventar 1996. Filiplić, Zdenka,

2. HR-DAPA-226 Mjesni narodni odbor Vrh, vodič kroz arhivski fond, s.a., Radaljac, Ljiljana, DAPA

3. HR-DAPA-226 Mjesni narodni odbor Vrh, Matični list fonda, s.a., DAPA

4. HR-DAPA-226 Mjesni narodni odbor Vrh, sumarni inventar 2016. Mrkonjić, Jasna, DAPA.

\section{DOPUNSKI IZVORI}

\section{Postojanje i mjesto čuvanja izvornika}

Izvornici se čuvaju u DAPA-i, na adresi Istarskoga razvoda 2, Pazin.

\section{Postojanje i mjesto čuvanja preslika}

Ne postoje izrađeni preslici fonda HR-DAPA-226 Mjesni narodni odbor Vrh.

\section{Dopunski izvori}

1. HR-DAPA-83 Kotarski narodni odbor Buzet 1945-1955.

2. HR-DAPA-119 Narodni odbor Općine Buzet 1952-1955.

\section{KONTROLA OPISA}

\section{Identifikator ustanove i opisa}

HR DAPA ObP-226/SI-1

\section{Pravila ili propisi}

ISAD (G), Opća međunarodna norma za opis arhivskog gradiva, Zagreb, Hrvatski državni arhiv, 2001.

ISAAR (CPF), Međunarodna norma arhivističkog normiranog zapisa za pravne i fizičke osobe te obitelji, 2. izd. (hrv. prijevod), Zagreb, Hrvatski državni arhiv, 2006.

\section{Napomena arhivista}

1. Na razini opisa Fonda korišteni su razrađeniji elementi iz ISAAR(CPF), 5.2. Područje opisa umjesto elementa opisa Upravna povijest (ISAD $(G)$ 3.2.2.).

2. Na razini opisa Fonda područje Kontrole opisa $(\operatorname{ISAD}(\mathrm{G}))$ zamijenjeno je razrađenijim oblikom ISAAR(CPF), 5.4. Područje kontrole. 
3. Za potrebe kontekstualizacije povijesti na razini Fonda korišten je element opisa Opći kontekst ISAAR(CPF).

\section{Izvori}

Podatci o fondovima navedeni su u »Dopunskim izvorima«. Službena su glasila navedena kako u bilješkama, tako i u »Izvorima ovlasti«.

\section{Status}

Dovršen i dostupan opis.

\section{Nadnevak nastanka, izmjena i brisanja}

Konačna je verzija obavijesnoga pomagala izrađena 2016. godine.

\section{ARHIVISTIČKI OPISI I INVENTARNI POPISI NIŽIH RAZINA FONDA}

\section{II/1. ORGANIZACIJA I UPRAVLJANJE}

\section{Signatura \\ Naslov \\ Vrijeme nastanka gradiva \\ Razina opisa \\ Količina i nosač jedinice opisa \\ Sadržaj}

\section{Plan sređivanja}

HR-DAPA-226/1

Organizacija i upravljanje

1947-1952

Serija

$1 / 3 \mathrm{kutije}, 0,03 \mathrm{~d} / \mathrm{m}$

Gradivo serije obuhvaća spise koji se odnose na ukidanje stvaratelja, odnosno likvidaciju Mjesnoga narodnog odbora Vrh, potom zapisnike sjednica organa upravljanja: IO-a, MNO-a, Plenuma, Zbora birača, potom Savjeta građana za poljoprivredu, Savjeta građana za prosvjetu, Savjeta građana za trgovinu i otkup te Planske komisije i Popisne mjesne komisije.

Unutar serije gradivo je raspoređeno na podserije te je sređeno kronološki.

Popis gradiva serije

\begin{tabular}{|l|l|l|l|l|}
\hline Signatura & Sadržaj/naslov gradiva & Raspon godina & Teh. jedinica & Napomena \\
\hline \multirow{2}{*}{1.1.} & Osnivanje, organizacija, ukidanje & 1952 & Kut. 1 & \\
\cline { 2 - 5 } & $\begin{array}{l}\text { Zapisnik o finaliziranju poslovanja i li- } \\
\text { kvidaciji MNO-a Vrh od 11. 5. 1952. }\end{array}$ & & & \\
\hline 1.2. & Organi upravljanja & & & \\
\hline 1.2 .1$. & Izvršni odbor & & & \\
\hline
\end{tabular}




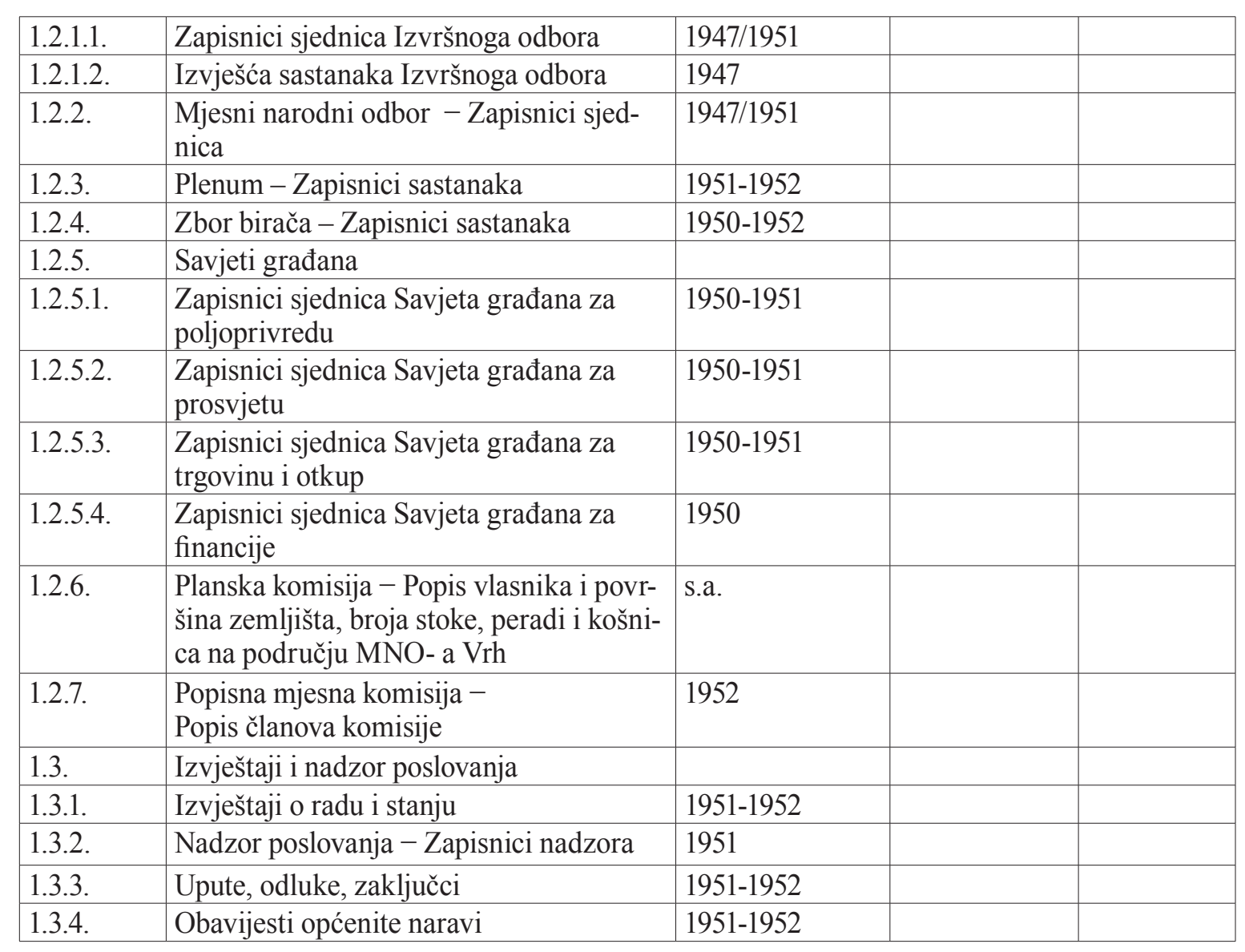

\section{II/2. EVIDENCIJE DOKUMENTACIJE}

Signatura

Naslov

Vrijeme nastanka gradiva

Razina opisa

Količina i nosač jedinice opisa

Sadržaj

\section{Plan sređivanja}

HR-DAPA-226/2

Evidencije dokumentacije

1947-1952

Serija

2 kutije, $0,09 \mathrm{~d} / \mathrm{m}$

Serija sadrži registraturna pomagala (urudžbene zapisnike) za poslovanje stvaratelja u cijelosti, potom zasebno urudžbene zapisnike Vojnoga odsjeka (referade) i Matičnoga ureda te ostale pomoćne evidencije, odnosno Registar izdavanja dokumenta MU.

Registraturna pomagala popisana su i razvrstana kronološki, na početku ona koja su se odnosila na cjelokupno poslovanje stvaratelja, a potom ona koja su se odnosila na poslovanje određenih službi. 


\section{Popis gradiva serije}

\begin{tabular}{|c|c|c|c|c|}
\hline Signatura & Sadržaj/naslov gradiva & Raspon godina & Teh. jedinica & Napomena \\
\hline 2.1. & Registraturna pomagala & & & \\
\hline 2.1./1 & $\begin{array}{l}\text { Urudžbeni zapisnik } \\
\text { br. } 1-347\end{array}$ & 1947 & Kut. 1 & \\
\hline $2.1 . / 2$ & $\begin{array}{l}\text { Urudžbeni zapisnik (obični) } 1947 . \\
\text { br. } 348 \text { - } 535 \\
\text { Urudžbeni zapisnik (povjerljivi) } 1951 . \\
\text { br. } 1-31\end{array}$ & 1947.1951 & & \\
\hline $2.1 . / 3$ & $\begin{array}{l}\text { Urudžbeni zapisnik } \\
\text { Br. } 1-824 \text { za } 1948 . \\
\text { Br. } 1-738 \text { za } 1949 . \\
\text { Br. } 1-693 \text { za } 1950 .\end{array}$ & $1948-1950$ & & \\
\hline 2.1./4 & $\begin{array}{l}\text { Urudžbeni zapisnik } \\
\text { Br. } 1 \text { - } 542 \text { za } 1951 . \\
\text { Br. } 1 \text { - } 117 \text { za } 1952 .\end{array}$ & $1951-1952$ & & \\
\hline $2.1 . / 5$ & $\begin{array}{l}\text { Urudžbeni zapisnik Vojnoga odsjeka } \\
\text { Br. } 1 \text { - } 33\end{array}$ & 1950 & & \\
\hline 2.1./6 & $\begin{array}{l}\text { Urudžbeni zapisnik Matičnoga ureda } \\
\text { Br. } 1 \text { - } 120 \text { za } 1950 . \\
\text { Br. } 1 \text { - } 193 \text { za } 1951 . \\
\text { Br. } 1 \text { - } 38 \text { za } 1952 .\end{array}$ & $1950-1952$ & & Izvan kutije \\
\hline $2.1 . / 7$ & $\begin{array}{l}\text { Registar izdavanja dokumenata Matič- } \\
\text { noga ureda } \\
\text { Br. } 1 \text { - } 23 \text { za } 1947 . \\
\text { Br. } 1 \text { - } 564 \text { za } 1948 . \\
\text { Br. } 1 \text { - } 631 \text { za } 1949 . \\
\text { Br. } 1 \text { - } 581 \text { za } 1950 . \\
\text { Br. } 1 \text { - } 353 \text { za } 1951 . \\
\text { Br. } 1 \text { - } 72 \text { za } 1952 .\end{array}$ & $1947-1952$ & Kut. 2 & \\
\hline
\end{tabular}

\section{II/3. DJELATNOST NARODNOGA ODBORA}

Signatura

Naslov

Vrijeme nastanka gradiva

Razina opisa

Količina i nosač jedinice opisa

Sadržaj
HR-DAPA-226/3

Djelatnost narodnoga odbora

1947-1952

Serija

Serija sadrži spise koji se odnose na djelatnost stvaratelja te se u užem smislu radi o sljedećim poslovima:

Komunalni poslovi - obuhvaćeni su spisi u svezi s nekretninama MNO-a, podatci o optantskoj imovini, rješenja o sekvestraciji, spisi u svezi s upravljanjem stambenim fondom/ zgradama te izgradnjom i održavanjem objekata. 
Narodna obrana/vojni odsjek - obuhvaćeni su popisi vojnih obveznika, spisi koji se odnose na predvojničku obuku, novačenje, vojne vježbe, logistiku, održavanje manifestacija te spisi općenite naravi u svezi s poslovima narodne obrane. Poljoprivreda - sadrži poljoprivredne planove, izvještaje, evidencije, potom spise u svezi sa zaštitom poljoprivrednih dobara, prinosa i sl. Uz navedeno sadrži i spise o stočarskoj proizvodnji, kao i o radu organizirane veterinarske službe te općenite obavijesti.

Prosvjeta - sadrži spise o obnovi školske zgrade te poduzetim mjerama protiv roditelja čija djeca ne pohađaju školu. Rad i radni odnosi - sadrži podatke o ljudskim resursima i raspoloživim planovima radne snage, spise u svezi s kadrovskim pitanjima, odnosno spise o postavljanju u službu i njezinu prestanku, potom podatke o poduzetim stegovnim mjerama i postupcima, ocjenjivanju službenika, kao i obavijesti općenite naravi.

Socijalno i zdravstveno staranje - sadrži spise koji se odnose na dodjele socijalnih pomoći u vidu hrane i ostalih potrepština ugroženim kategorijama stanovništva, spise u svezi s invalidskim pitanjima, spise o zdravstvenoj skrbi za djecu, upute, odluke, zaključke, kao i obavijesti općenite naravi iz ovoga područja djelatnosti.

Trgovina, opskrba, obrt i privreda - uključeni su planovi (raspodjele robe te planovi otkupa, distribucije i raspodjele prehrambenih artikala i izvještaji o navedenim akcijama). Uz navedeno sadrži upute, odluke, zaključke, kao i obavijesti općenite naravi u svezi s ovim područjem djelatnosti.

Unutrašnji poslovi i matični ured - obavijesti/odgovori optantima temeljem njihovih zahtjeva za napuštanjem zemlje, odnosno optiranjem, potom potvrde o uporabi talijanskoga jezika, nadalje prekršajne prijave, spise u svezi s izdavanjem osobnih dokumenata. Spisi MU sadrže dokumente o polaganju stručnih ispita za matičare, potom prijave sklapanja braka za Krušvare i Vrh te stalne biračke popise s područja nadležnosti MNO-a Vrh.

Financijsko poslovanje - dokumentacijom su obuhvaćeni zapisnici o pregledu obračuna i uplatama državne akumulacije, potom odluke o prihvaćanju proračuna te prijave i obračune poreza, odnosno ostvarenoga dohotka preko naplata poreza. Uz navedeno serija sadrži upute, odluke i zaključke te općenite obavijesti koje se odnose na financijsko poslova-

Plan sređivanja nje stvaratelja.

Unutar serije gradivo je razvrstano na podserije, unutar kojih je po potrebi razvrstano na još niže jedinice i sređeno je kronološki. 


\section{Popis gradiva serije}

\begin{tabular}{|c|c|c|c|c|}
\hline Signatura & Sadržaj/naslov gradiva & Raspon godina & Teh. jedinica & Napomena \\
\hline 3.1. & Komunalni poslovi - nekretnine & & Kut. 2 & \\
\hline \multirow[t]{2}{*}{ 3.1.1. } & $\begin{array}{l}\text { Nekretnine u posjedu i/ili pod upravom } \\
\text { MNO-a }\end{array}$ & 1951-1952 & & \\
\hline & $\begin{array}{l}\text { Smještaj MNO-a Vrh } \\
\text { Ugovori o zakupu - najmu nekretnina } \\
\text { kojima upravlja MNO }\end{array}$ & & & \\
\hline 3.1.2. & Optantska imovina & & & \\
\hline 3.1.2.1. & Raspolaganje i upravljanje imovinom & 1951-1952 & & \\
\hline 3.1.2.2. & Rješenja o sekvestraciji & 1951 & & \\
\hline 3.1.2.3. & Prijenos vlasništva nad nekretninama & 1951 & & \\
\hline 3.1 .3$. & $\begin{array}{l}\text { Stambena djelatnost (upravljanje stambe- } \\
\text { nim zgradama) }\end{array}$ & 1951 & & \\
\hline \multirow[t]{2}{*}{ 3.1.4. } & Infrastruktura & 1951-1952 & & \\
\hline & Izgradnja i održavanje objekata & & & \\
\hline 3.2. & Narodna obrana/Vojni odsjek & & & \\
\hline 3.2.1. & $\begin{array}{l}\text { Planovi - Plan obezbijeđenja za MNO } \\
\text { Vrh (P.A.Z.) }\end{array}$ & 1951 & & $\begin{array}{l}\text { Radi se o } \\
\text { Planu pro- } \\
\text { tuavionske } \\
\text { zaštite }\end{array}$ \\
\hline 3.2 .2$. & Vojni obveznici & & & \\
\hline 3.2.2.1. & $\begin{array}{l}\text { Predvojnička obuka, novačenje, pozivi na } \\
\text { vježbe vojnih obveznika }\end{array}$ & $1949-1952$ & & \\
\hline 3.2.2.2. & $\begin{array}{l}\text { Popisi vojnih obveznika pripadnika NOV- } \\
\text { a (sudionika NOR-a) }\end{array}$ & s.a. & & \\
\hline 3.2.2.3. & $\begin{array}{l}\text { Popis vojnih obveznika predviđenih za } \\
\text { sudjelovanje na vojnim vježbama }\end{array}$ & $1949 / 1951$ & & \\
\hline 3.2.2.4. & Edukacija kadrova & $1949-1950$ & & \\
\hline \multirow[t]{2}{*}{3.2 .3} & Logistika & 1950-1951 & & \\
\hline & $\begin{array}{l}\text { Vojni transport - popisi stoke/tegleće } \\
\text { marve i stočnih prijevoznih sredstava za } \\
\text { potrebe vojske }\end{array}$ & & & \\
\hline \multirow[t]{2}{*}{ 3.2.4. } & Manifestacije i nagrade & $1950-1951$ & & \\
\hline & $\begin{array}{l}\text { Popisi istaknutih omladinaca predviđenih } \\
\text { za sudjelovanje u nošenju Titove štafete te } \\
\text { nagrađivanje i pohvaljivanje }\end{array}$ & & & \\
\hline 3.2.5. & Obavijesti općenite naravi & 1950-1951 & & \\
\hline 3.3. & Poljoprivreda & & & \\
\hline 3.3.1. & Poljoprivredni planovi & 1951-1952 & & \\
\hline 3.3.2. & Izvještaji o poljoprivrednim radovima & 1951-1952 & & \\
\hline 3.3.3. & Poljoprivredne evidencije & & & \\
\hline 3.3.3.1. & $\begin{array}{l}\text { Poljoprivredne evidencije/podatci o povr- } \\
\text { šinama zemljišta }\end{array}$ & $1951-1952$ & & \\
\hline 3.3.3.2. & $\begin{array}{l}\text { Evidencija poljoprivrednih proizvođača - } \\
\text { poreznih obveznika }\end{array}$ & s.a. & & \\
\hline
\end{tabular}




\begin{tabular}{|c|c|c|c|c|}
\hline \multirow[t]{2}{*}{ 3.3.4. } & Poljoprivredna zaštita & $1951-1952$ & & \\
\hline & $\begin{array}{l}\text { Zaštita poljoprivrednih dobara (poljo- } \\
\text { privrednih površina, usjeva i šumskoga } \\
\text { fonda) }\end{array}$ & & & \\
\hline \multirow[t]{2}{*}{ 3.3.5. } & Stočarstvo & 1951-1952 & & \\
\hline & $\begin{array}{l}\text { Proizvodne kvote uzgoja i praćenja stanja } \\
\text { stočnoga fonda }\end{array}$ & & & \\
\hline 3.3 .6$. & Veterinarska služba & & & \\
\hline 3.3.6.1. & Zaštita zdravlja domaćih životinja & 1951-1952 & & \\
\hline 3.3.6.2. & Cijepljenje stoke i pasa u domaćinstvima & $1951-1952$ & & \\
\hline 3.3.7. & Obavijesti općenite naravi & $1951-1952$ & & \\
\hline 3.4. & Prosvjeta & & & \\
\hline 3.4.1. & $\begin{array}{l}\text { Obnova školske zgrade i materijalna pot- } \\
\text { pora učiteljima }\end{array}$ & 1951 & & \\
\hline 3.4.2. & $\begin{array}{l}\text { Mjere i postupci protiv roditelja/staratelja } \\
\text { učenika koji ne pohađaju nastavu u školi }\end{array}$ & 1951 & & \\
\hline 3.5. & Rad i radni odnosi & & & \\
\hline \multirow[t]{2}{*}{ 3.5.1. } & Raspolaganje ljudskim resursima & 1951 & & \\
\hline & $\begin{array}{l}\text { Planovi raspolaganja i aktivizacije radne } \\
\text { snage i radnih obveznika }\end{array}$ & & & \\
\hline 3.5 .2$. & Kadrovska pitanja & & & \\
\hline 3.5.2.1. & Postavljenja i prestanak službe & 1951 & & \\
\hline 3.5.2.2. & Stegovne mjere i postupci & $1951-1952$ & & \\
\hline 3.5.2.3. & Ocjenjivanje službenika & 1952 & & \\
\hline 3.5.2.4 & Obavijesti općenite naravi & $1951-1952$ & & \\
\hline 3.6. & Socijalno i zdravstveno staranje & & & \\
\hline 3.6.1. & Dodjela socijalne pomoći & & & \\
\hline 3.6.1.1. & Pregledi raspodjele hrane & 1951 & & \\
\hline 3.6.1.2. & $\begin{array}{l}\text { Korisnički podatci o kategorijama prima- } \\
\text { telja socijalne pomoći }\end{array}$ & 1951 & & \\
\hline 3.6 .2 & Invalidska pitanja & & & \\
\hline 3.6.2.1. & $\begin{array}{l}\text { Rješenja za isplate invalidnina i ostalih } \\
\text { prinadležnosti invalidima/uživaocima } \\
\text { socijalne pomoći }\end{array}$ & $1951-1952$ & & \\
\hline 3.6.2.2. & Skrb o ratnim vojnim invalidima & 1951 & & \\
\hline \multirow[t]{2}{*}{ 3.6.3. } & Zdravstvena skrb & 1951 & & \\
\hline & Cijepljenje djece & & & \\
\hline 3.6.4. & Upute, odluke, zaključci & 1951-1952 & & \\
\hline 3.6.5. & Obavijesti općenite naravi & $1951-1952$ & & \\
\hline 3.7. & Trgovina, opskrba, obrt i privreda & & Kut. 3 & \\
\hline \multirow[t]{2}{*}{ 3.7.1. } & Planovi raspodjele robe & 1951-1952 & & \\
\hline & $\begin{array}{l}\text { Planovi otkupa, distribucije i raspodjele } \\
\text { prehrambenih artikala i ostale robe }\end{array}$ & & & \\
\hline 3.7.2. & Izvještaji o opskrbi potrošača & 1951 & & \\
\hline 3.7.3. & Upute, odluke, zaključci & 1951 & & \\
\hline 3.7.4. & Obavijesti općenite naravi & $1951-1952$ & & \\
\hline
\end{tabular}




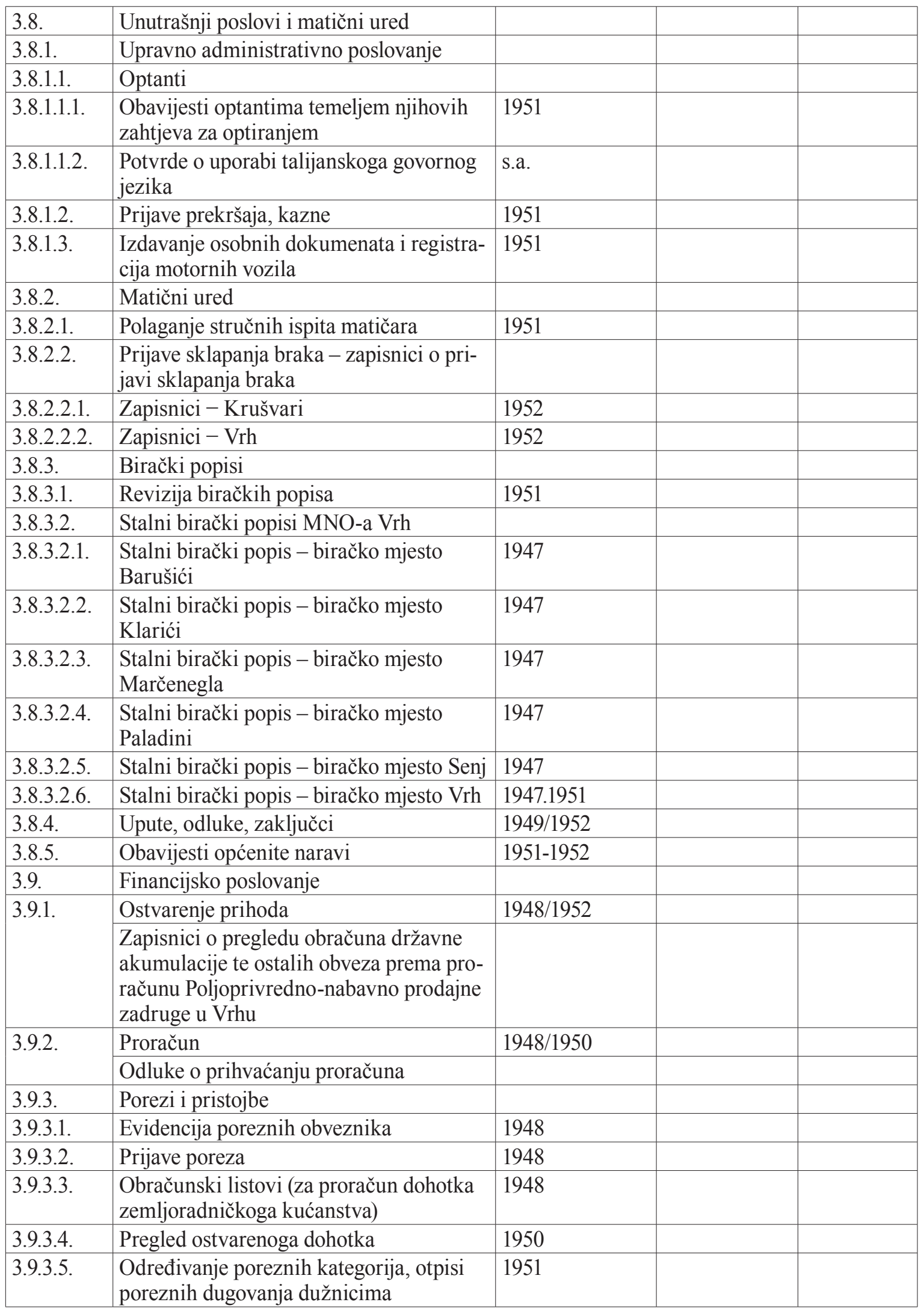




\begin{tabular}{|l|l|l|l|l|}
\hline 3.9.4. & Upute, odluke, zaključci & $1950-1952$ & & \\
\hline 3.9.5. & Obavijesti općenite naravi & $1951-1952$ & & \\
\hline
\end{tabular}

\section{SAŽETAK}

\section{Sumarni inventar fonda Mjesni narodni odbor Vrh 1947. - 1952.}

Mjesni narodni odbor Vrh započeo je djelovanje 1947. godine, kao lokalno upravno tijelo za područje svoje nadležnosti. Kao najviši organ vlasti, osiguravao je nesmetano odvijanje svih aktivnosti s područja o kojima je skrbio: gospodarstva, poljoprivrede, komunalnih poslova, trgovine i obrta, financija, zdravstvene i socijalne skrbi itd. Uz navedeno, obavljao je i poslove matičarstva, evidentiranja stanovništva, nadzirao rad mjesnih društvenih organizacija i sl. Sazivao je redovite i izvanredne sjednice na kojima se raspravljalo o važnim pitanjima za lokalnu društvenu zajednicu u danom trenutku. Promjenom zakonskoga okvira te prestankom djelovanja stvaratelja, gradivo je predmetnoga fonda po službenoj dužnosti iz pismohrane SO Buzet, zajedno s gradivom drugih bivših upravnih tijela s područja Buzeštine, preuzeto u Državni arhiv u Pazinu. Po preuzimanju u Arhiv, gradivo je predmetnoga fonda bilo osnovno sređeno i popisano, a arhivistička je obrada obavljena 2016. godine. Gradivo je sređeno razdiobom na serije, prema sadržaju odnosno području djelatnosti ili funkciji na koju se odnosi: Organizacija i upravljanje, Općenito poslovanje, Uže poslovanje i Financijsko poslovanje. 


\section{SUMMARY}

\section{The Summary Inventory of the Fonds of the Local People's Committee of Vrh 1947 - 1952}

The Local People's Committee of Vrh began its activity in 1947 as a local administrative authority covering the area of its competence. As the highest authority, it ensured the smooth running of all activities under his responsibility - economy, agriculture, public utilities, trade and crafts, finance, health and social care, etc. Furthermore, it also carried out the activities of registry, population registration, control of the work of local social organizations etc. It called regular and extraordinary sessions where current important issues for the local community were discussed. Following the change of the legal framework and termination of the activities of the creator, the material of the Fonds was transferred ex officio from the records of the Buzet Municipality Assembly, together with the archives of other former administrative bodies in the area of Buzet, to the State Archives of Pazin. After being taken over by the Archive, the archives of the Fonds were only basically arranged and listed, while archival processing was carried out in 2016. The archives were arranged in series, according to the content or area of activity or function referred to: Organization and Management, General Affairs, Specific Affairs and Financial Operations

\section{RIASSUNTO}

\section{Inventario sommario del fondo Comitato popolare locale di Vetta 1947 - 1952}

Il Comitato popolare locale di Vetta cominciò con la sua attività nel 1947 quale organo amministrativo locale nell'ambito della sua competenza. In quanto massimo organo del potere, assicurava il regolare svolgimento di tutte le attività del suo ambito: economia, agricoltura, lavori comunali, commercio e artigianato, finanze, assistenza sanitaria e sociale, ecc. Inoltre, svolgeva iscrizioni all'anagrafe, registrazioni degli abitanti, controllava il lavoro delle locali organizzazioni sociali e simile. Convocava sedute regolari e straordinarie in cui si discutteva di questioni attuali importanti per la locale comunità sociale. Con il cambiamento del quadro normativo e con la cessazione d'attività del soggetto produttore, il materiale del fondo in questione fu trasferito d'ufficio dall'archivio dell'AC di Pinguente, insieme al materiale prodotto da altri organi amministrativi del territorio di Pinguente, all'Archivio di Stato di Pisino. In seguito al trasferimento all'Archivio, il materiale del fondo in questione fu ordinato e registrato, mentre la sistematizzazione archivistica approfondita fu effettuata nel 2016. Il materiale fu ordinato tramite la divisione in serie, a seconda del contenuto ossia dell'ambito dell'attività oppure della funzione a cui si riferisce: Organizzazione e amministrazione, Attività generale, Attività specifica e Attività finanziaria. 